\title{
EFFECTIVENESS OF GLYPHOSATE AND 2.4 D AMIN HERBICIDES TO CONTROL WEEDS UNDER Shorea selanica B1. PLANTATION IN CARITA TRIAL GARDEN, BANTEN
}

\author{
Ari Wibowo ${ }^{1}$ and Muhamad Nazif ${ }^{1}$
}

\begin{abstract}
ABSTARCT
A trial was carried out in Carita, West Java, to identify the effectiveness of Glyphosate and 2.4 D Amin Herbicide to control weeds under Shorea selanica Bl. plantation. The trial was conducted through the application of Glyphosate and 2.4 D Amin Herbicide with dosages of 5, 6, 7, 8 and 9 liter per ha and compared with Glyphosate herbicide 5 liter per ha, manual treatment, and control (no treatment). The result showed that Glyphosate and 2.4 D Amin Herbicide could be used to control weeds in order to maintaining S. selanica Bl. plantation. Minimum dosage of 6 liter/ha was effective to control weeds such as Chromolaena odorata DC, Mikania micrantha Will, Lantana camara L, Imperata cylindrica Beauv., Melastoma malabatbricum L, and Boreria latifolia Bl. Furthermore, there was no symptom of poison on S. selanica Bl. plantation after herbicide application with all dosages applied.
\end{abstract}

Keywords: Shorea selanica Bl. plantation, weed control, herbicide

\section{INTRODUCTION}

Shorea selanica $\mathrm{Bl}$. is a tree species of dipterocarps family natives to Moluccas areas. In its natural habitat, the species is found on low land tropical rain forest and can grow on soil that contains lime (Whitmore et al., 1989). To fulfill the need of woods that cannot be supplied from natural forests, industrial forest plantations need to be developed. Species of Dipterocarps are preferred and mostly selected as raw materials for construction woods.

One of the issues that often arise in forest plantation includes the growth of some weeds that compete with Shorea spp., especially during their young stage or under five years when sunlight can penetrate forest floor and create favorable condition for the growth of weeds. Growth of weed species is intensive due to open areas after land clearing for preparation of plantation. Weeds are species that grow on undesirable site and disturb the growth of main plantation. Disadvantages due to weed's growth include slow rate of growth and yield due to competition, reduction of plantation quality, reduction of yields because of attack by pest, disease that increase on favorable conditions and some weeds that produce poisonous allelophatic materials to main plantation.

In order to maintain $S$. selanica Bl. plantation from disturbance caused by annoying weeds, a trial was carried out using systemic herbicides with active ingredients of Glyphosate and 2,4 D-Amin. Herbicide that has been commonly used with active ingredients of glyphosate was also applied as comparisons, as well as mechanical control through cutting.

\footnotetext{
${ }^{1}$ Plantation Forest Research and Development Center, Bogor
} 


\section{METHODOLOGY}

\section{A. Site Description}

A study was done in The Experimental Garden of Carita, $\pm 150 \mathrm{~km}$ west of Jakarta. Carita Experimental Garden consists of Carita I with 19 plots and Carita II with 46 plots. Trial of weed control was carried out in Carita II that has been planted with Shorea selanica since 2000-2001. Shorea selanica is one of the species planted in Carita mainly for silvicultural study. It consists of only one class age.

Based on classification by Schmidt and Ferguson (1951), Carita trial site has A climatic type or wet climate with annual rainfall of $3,959 \mathrm{~mm}$. The area is a hilly topography and located $100 \mathrm{~m}$ above sea level. Soil in this area belongs to old gray alluvium with secondary mineral of clay deposit. (Soil Research Institute, 1966). Among dominant undergrowth species in the study site include Chromolaena odorata and Mikania micrantha.

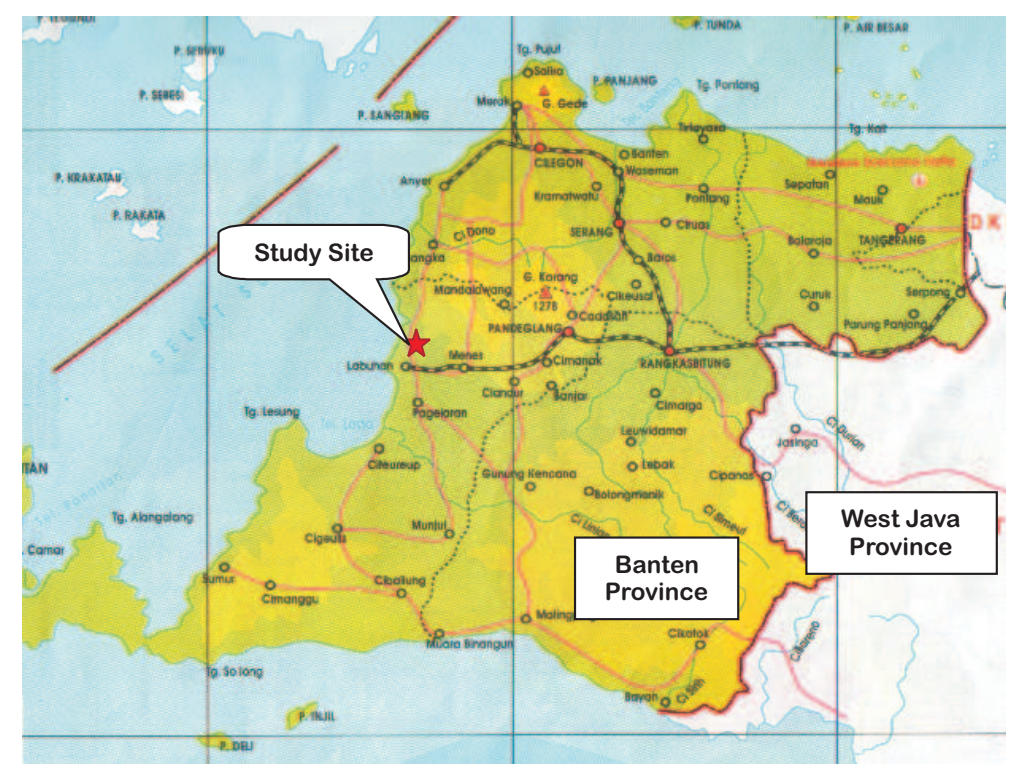

Figure 1. Indicative map of study site in Carita, Banten

\section{B. Tools and Materials}

Materials used in this research included herbicides with active ingredients of Glyphosate and 2,4 D-Amin, plastic bags, markers, paint, zinc plate, and plastic rope. Tools used included camera, counter, brush, measurement tape, machete, grass clippers, frames, nozzles, measurement glass and hand sprayer. 


\section{Methods of Data Collection and Analysis}

Parameters observed in this study consisted of weed domination, weed biomass, and poisonous level of the herbicides to main plantation.

\section{Weed Domination}

Inventory of weed species was carried out in plantation forest with a main plantation of four year old S. selanica. Sampling plots of $1 \mathrm{~m}$ x $1 \mathrm{~m}$ were used to identify weed species. The plots were laid under plantation with a $20 \mathrm{~m}$ distance between lines and a $5 \mathrm{~m}$ distance between centers of plots. The total 25 plots was made for undergrowth vegetation analysis. The number and the crown projection of each species found within the sampling plots were recorded. This method was applied to identify the species, species density, frequency and dominance. Species domination is calculated using Important Value Indices (IVI) which are the total of relative frequency, relative domination and relative frequency of each species (Odum, 1971). Herbariums were collected for identification in Forest and Nature Conservation Research and Development Center Laboratory, Bogor. Dominant species were those with the highest important value indices on particular site.

\section{Weed Control}

Weed control was carried out using Glyphosate and 2,4 D-Amin herbicide, compared to a control treatment of a herbicide with active ingredient of Glyphosate. Dosages of 5, 6, 7, 8, and 9 liter/ha of Glyphosate and 2,4 D-Amin, and 6 liter/ha of Glyphosate herbicide were applied. Twenty four plots of $20 \mathrm{~m}$ x $10 \mathrm{~m}$ each were made for the application of eight treatments and three replications. The herbicide was applied through circular spray with spray radius of 2 meter around the plantation. The results of herbicide application were compared with control and manual plots. Measurement to the result of application was carried out with interval of 1,2 and 3 months after herbicide application.

\section{Weed Biomass}

Five plots of $0.5 \mathrm{~m} \times 0.5 \mathrm{~m}$ each were made on areas sprayed with herbicide for each treatment. Samples were taken by cutting all weed biomass up to soil surface. Weeds were separated according to live (green) and dead parts, and weighted. The living (green) and dead parts of the weeds were separated and then weighted. Water contents of biomass were measured by weighting the samples before and after oven dried (constant weight). Weed biomass was measured 1,2 and 3 months after the application of herbicide treatments.

\section{Poison Level of Herbicide}

Poison level of herbicide to main plantation was observed after the application of herbicides using visual score as follows (Commission of Pesticide, 1994): 
$0=$ No poison, $0-5 \%$ shape and color of young leaves slightly change.

$1=$ Light poison, $6-10 \%$ abnormal shape and color of young leaves.

$2=$ Medium poison, $11-20 \%$ abnormal shape and color of young leaves.

$3=$ Heavy poison, 21- 50\% abnormal shape and color of young leaves.

$4=$ Severely poison, $50 \%$ abnormal shape and color of young leaves, dry and fall, and plantation might die.

To determine herbicide poison index to main plantation, scoring data were calculated using the following formulae:

$$
I=\frac{\mathrm{N}_{1}+\mathrm{N}_{2}+\mathrm{N}_{3}+\ldots \ldots \mathrm{N}_{\mathrm{n}}}{\mathrm{N}_{\max } \cdot \mathrm{X}} \times 100 \%
$$

Remark:

I $\quad=$ Index of herbicide poison in percent

$\mathrm{N}_{1-\mathrm{n}} \quad=$ Total score of sample plots of particular treatment

Nmax $=$ Highest score value

$\mathrm{X}=$ Number of treatment.

Data analysis to identify the significant level of each treatment of weed control was carried out according to randomized block design, and level of differences were stated for $5 \%$ and $1 \%$ levels (Steel and Torrie, 1981).

\section{RESULTS AND DISCUSSION}

\section{A. Observation of Weed Issue}

Visual observation to dominant weeds showed that some weed species have caused disturbances to young $S$. selanica plantation, due to competition of site and climbing the plantation. These dominant species included C. odorata, M. micrantha, Lantana camara, Imperata cylindrica, Melastoma malabathricum, and Borreria latifolia.

In study area, the important weed species was, $C$. odorata. The species could reach 2.5 meter height, and it was a serious weed of pastures, forests, orchards and commercial plantations. In India, it occupies pastures, marginal lands and open areas. It has become a menace in coconut, rubber, oil palm, tea, teak, coffee, citrus, and other plantations. In forest ecosystem, it increases the cost of seedling production in nurseries, hampers harvesting operations in the forests, and affects the overall productivity of the forest ecosystem. During the dry season, it can be a serious fire risk in the forest (Singh, 2001). 


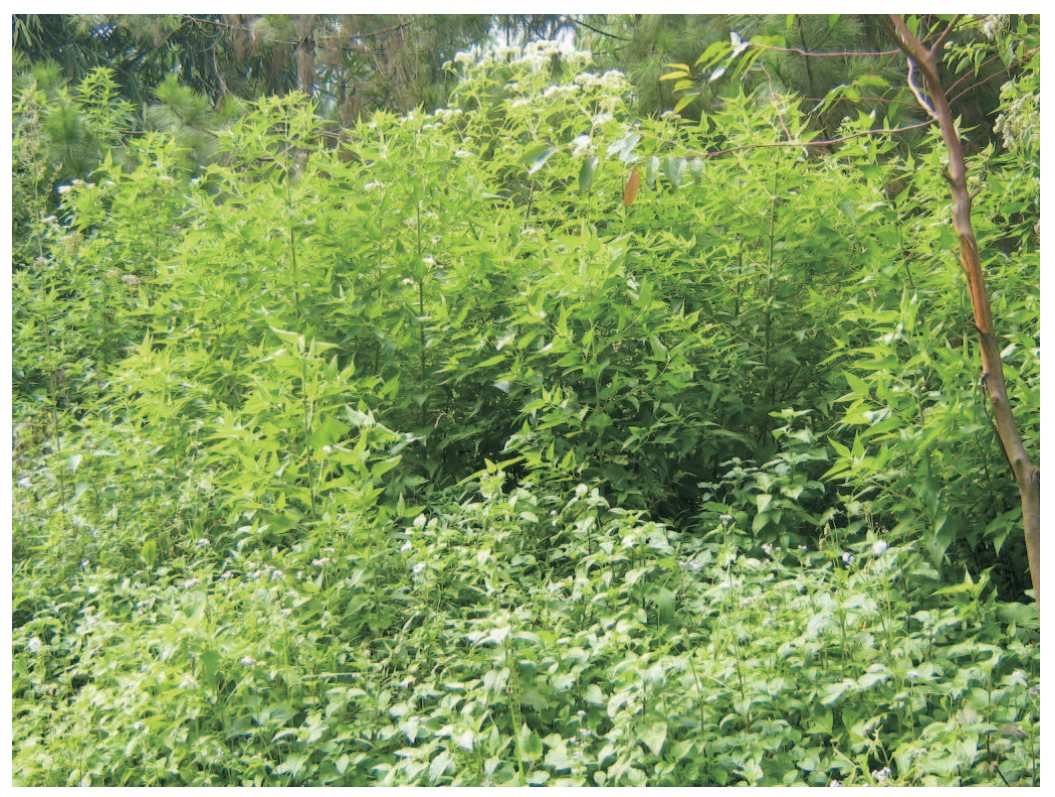

Figure 2. Chromolaena odorata as a dominant weed species in Indonesia, as well as in the study site.

Mikania micrantha was also found in study area. This species climbed of the main plantation and covered the crown and disturbed it. M. micrantha is an exotic perennial weed, originally from Central and South America, reported to be widespread in the tropics, posing serious threat to various production systems such as agriculture, forest plantations and natural forests (Moraleedharan and Anitha, 2001). M. micrantha is found to grow well, up to an elevation of 1,000 meter. It is herbaceous climber that grows very well in low lying soils where adequate moisture is available throughout the year. (Gogoi, 2001).

Another important weed found in the study site was L. camara. This species is an obnoxious weed that is highly light demanding, therefore activities to open forests, clear felled forests, and young plantations are particularly vulnerable. It has capability to choke all other vegetation and becomes the dominant species (Sushilkumar, 2001).

Probably, the most important weed species in Indonesia is alang-alang (I. cylindrica L. Raeuschel). In Indonesia, alang-alang grassland reached 8.5 million ha, and this species up to present is still categorized as an annoying weed. Area that is dominated by this species belongs to unproductive critical land and rehabilitation is required to establish more productive forest area. There is a strong relationship between fire and the growth of alang-alang (Wibowo, 2006). Fortunately in the study area, alang-alang was not the most dominant species. This might be caused by the area that did not get full light intensity or enough shade due to availability of plantation. 


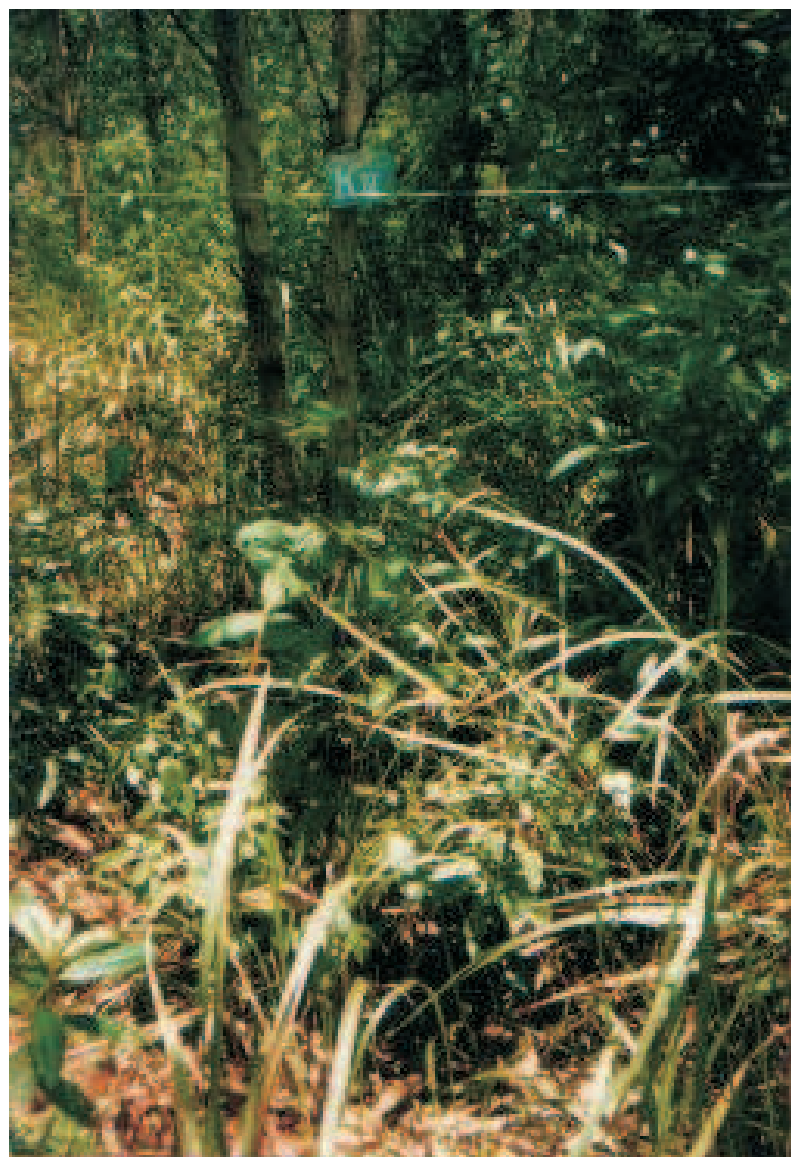

Figure 3. Condition of weed under Shorea selanica plantation

\section{B. Dominant Weeds}

In location of three year old S. selanica, there were 30 species of undergrowth found as shown in Table 1. Dominant species were those that have high important value indices in particular site. These dominant species could be categorized as weeds because they were dominant, dense, and had a potency to disturb main plantation, through competition of nutrient, light, water and physical damage. Therefore, weed control by application of herbicides and manual control could be applied. 
Table 1. List of important value indices (IVI) of undergrowth species under three year old S. selanica plantation in Carita, Banten.

\begin{tabular}{|c|c|c|c|c|c|c|}
\hline \multirow[b]{2}{*}{ No } & \multirow[b]{2}{*}{ Species } & \multicolumn{5}{|c|}{ Relative } \\
\hline & & Family & $\begin{array}{c}\text { Relative } \\
\text { Density } \\
(\%)\end{array}$ & $\begin{array}{c}\text { Fre - } \\
\text { quency } \\
(\%)\end{array}$ & $\begin{array}{c}\text { Relative } \\
\text { Dominance } \\
(\%)\end{array}$ & $\begin{array}{l}\text { IVI } \\
(\%)\end{array}$ \\
\hline 1 & Chromolaena odorata & Comp & 67.28 & 19.81 & 50.53 & 137.62 \\
\hline 2 & Mikania micrantha & Gram & 6.48 & 4.54 & 7.71 & 18.73 \\
\hline 3 & Lantana camara & Rub & 3.73 & 5.89 & 3.06 & 12.68 \\
\hline 4 & Imperata cylindrica & Comp & 2.81 & 5.08 & 3.4 & 11.29 \\
\hline 5 & Melastoma malabathricum & Melast & 1.35 & 5.63 & 3.9 & 10.88 \\
\hline 6 & Borreria latifolia & Verb & 2.63 & 4.28 & 3.13 & 10.04 \\
\hline 7 & Scleria sumatrensis & Cyper & 0.83 & 4.02 & 2.11 & 6.96 \\
\hline 8 & Vitexpubescens & Verb & 1.06 & 3.21 & 2.03 & 6.3 \\
\hline 9 & Mimosa pudica & Mim & 1.23 & 2.67 & 1.77 & 5.67 \\
\hline 10 & Cynodon dactylon & Gram & 1.16 & 2.67 & 1.84 & 5.67 \\
\hline 11 & Clibadium surinamense & Comp & 0.97 & 3.21 & 1.44 & 5.62 \\
\hline 12 & Andropogon bolepensis & Gram & 1.18 & 2.67 & 1.76 & 5.61 \\
\hline 13 & Blumea lacera & Comp & 0.73 & 3.21 & 1.55 & 5.48 \\
\hline 14 & Gleichenia linearis & Gleich & 0.64 & 3.21 & 1.39 & 5.24 \\
\hline 15 & Clidemia birta & Melast & 0.62 & 2.67 & 1 & 4.3 \\
\hline 16 & Trema orientalis & Ulm & 0.73 & 2.41 & 1.15 & 4.28 \\
\hline 17 & Maletus sp. & Euph & 0.81 & 2.13 & 1.26 & 4.2 \\
\hline 18 & Rotbboelia glandulosa & Gram & 0.61 & 2.13 & 1.37 & 4.11 \\
\hline 19 & Cyrtococcum oxyphyllum & Gram & 0.45 & 2.41 & 1.16 & 4.02 \\
\hline 20 & Spatbolobus littoralis & - & 0.66 & 2.13 & 1.05 & 3.83 \\
\hline 21 & Axonopus compressus & Gram & 0.64 & 2.13 & 1.02 & 3.79 \\
\hline 22 & Piper aduncum & Pip & 0.59 & 2.13 & 1.05 & 3.77 \\
\hline 23 & Hyptis capitata & Lob & 0.4 & 1.87 & 0.84 & 3.1 \\
\hline 24 & Cyperus sp. & Cyper & 0.38 & 1.61 & 0.97 & 2.96 \\
\hline 25 & Centrocema pubescens & Pap & 0.45 & 1.61 & 0.85 & 2.91 \\
\hline 26 & Leea indica & Vit & 0.35 & 1.61 & 6.71 & 2.66 \\
\hline 27 & Stachytarpheta dicotama & Verb & 0.29 & 1.61 & 0.6 & 2.5 \\
\hline 28 & Cyrtococcum sylvatyca & Comp & 0.38 & 1.33 & 0.65 & 2.35 \\
\hline 29 & Blumea sylvatica & Comp & 0.29 & 1.06 & 0.56 & 1.92 \\
\hline 30 & Eleusine indica & Gram & 0.16 & 0.52 & 0.19 & 0.87 \\
\hline
\end{tabular}


Chromolaena odorata was the most dominant weed species in study area. This species originated from Central and South America and introduced in Java via Thailand (hence called 'Siam Weed' then spread throughout Indonesia; also in Australia, Northern India, South Africa and Peru. The species prefers well-drained sites, sunny or slightly shaded areas (dies under a closed canopy), in brushwood, abandoned land and wastelands. Invades clearings rapidly, grows very quickly and has an enormous seed production. There might be allelopathic substances present, and not attacked by insects, perhaps because of a repellent oil. Occurs from 50-1000 $\mathrm{m}$ alt. Flowers in Java in August-September; else where after the rainy season. (http//.nbin.biotrop.org).

\section{Trial of Weed Control}

Weed control has the objective to reduce weed population below economic or ecological threshold. It is expected that through weed control, main plantation could grow well and the growth of weed could be suppressed. Control of weed is usually carried out through mechanical control or and chemical control. For this trial, mechanical control was carried out manually using machetes to cut undergrowth up to soil surface. All undergrowths within 2 meter perimeter of main plantation were cut and the results were compared with control plots and application using herbicides.

The average weed biomass that consisted of leaves and branches of weeds after application of Glyphosate and 2,4 D-Amin herbicide up to three months application are presented in Table 2 .

Table 2. Biomass of weed under S. selanica plantation after application of Glyphosate and 2,4D-Amin herbicide

\begin{tabular}{|c|c|c|c|c|c|c|c|c|}
\hline No & Treatment & Dosage/ha & 1 Mont & & 2 Mon & & 3 Mont & \\
\hline 1 & $\begin{array}{l}\text { Glyphosate and } \\
2,4 \text { D-Amin }\end{array}$ & $5 \mathrm{lt}$. & 11,562 & a & 13,125 & a & 13,750 & $a$ \\
\hline 2 & $\begin{array}{l}\text { Glyphosate and } \\
2,4 \text { D-Amin }\end{array}$ & $6 \mathrm{lt}$. & 6,587 & b & 3,187 & b & 1,125 & b \\
\hline 3 & $\begin{array}{l}\text { Glyphosate and } \\
2,4 \text { D-Amin }\end{array}$ & $7 \mathrm{lt}$. & 5,687 & bc & 2,562 & bc & 0,875 & b \\
\hline 4 & $\begin{array}{l}\text { Glyphosate and } \\
\text { 2,4 D-Amin }\end{array}$ & 8 lt. & 5,375 & c & 2,312 & bc & 0,687 & b \\
\hline 5 & $\begin{array}{l}\text { Glyphosate and } \\
2,4 \text { D-Amin }\end{array}$ & $9 \mathrm{lt}$. & 5,125 & c & 2,062 & c & 0,562 & b \\
\hline 6 & Glyphosate & 6 lt. & 5,625 & c & 2,625 & bc & 0,937 & b \\
\hline 7 & Manual & - & 2,250 & d & 5,570 & d & 8,125 & c \\
\hline 8 & Control & - & 13,875 & e & 14,187 & e & 14,500 & $\mathbf{a}$ \\
\hline
\end{tabular}

Remarks: Figures followed by similar letter are not significantly different at 99\% level

Table 2 shows that one month after herbicide application, there was significant different between herbicide treatment and control plot. One month after herbicide application, active ingredients of Glyphosate and 2,4 D-Amin caused weeds to die at all 
dosages applied. Two months after application, there was still significant differences between all herbicides treatments, manual plots compared with control. However, among herbicide treatments, dosages of more than 7 liter/ha did not show significant differences.

After three months, there was still significant different between all herbicide treatments (except 5 liter/ha), and manual plots compared with control, but among herbicide treatments, dosages of more than 6 liter/ha did not show significant differences.

Results of this trial showed that the minimum dosage of 6 liter/ha of Glyphosate and 2, 4 D-Amin was still effective to control weeds under $S$. selanica plantation up to three months after application. In addition, manual treatment and application using only Glyphosate also showed significant different with control plots. Study by Nazif (1992) showed that Glyphosate was also effective to control weeds dominated by narrow leave weeds. This means that maintenance of plantation can also be done by manual and Glyphosate herbicide. Therefore, the consideration of herbicide application in the field based on its effectiveness could be the availability of herbicide in the market, price, and effect of the herbicide to main plantation. Meanwhile, the consideration of manual application in extensive area of forest plantation could be the availability of labor, time, and cost.

The best time to control weed under plantation is when the plantation still in its early stage of growth, or age class I. During the early stage, plantation needs to survive and under critical condition to compete with disturbances such as weeds.

One important thing that should be considered for weed control is vulnerability of plantation area to forest fire. After application of weed control, there would be high amount of dry biomass in a forest area as potential fuel for forest fires. Therefore, application of weed control should be done after dry season or in the beginning of rainy season to avoid forest fire.

\section{d. Poison level of herbicide to Shorea selanica plantation}

From the observation carried out up to three months after herbicide application, it was found that there were no symptoms of poison to main plantation at all dosages of applied herbicides. Therefore, the value of scoring was 0 , meaning that all herbicide treatment through circular spraying had been tolerated by main plantation. Measurement of dimension (height and diameter) of main plantation for all treatments applied. Main plantation of S. selanica had an average of $5.2 \mathrm{~cm}$ average in breast height diameter and 4.3 meter in height after 3 months of application.

However, a study has proven that direct application of herbicide to main plantation (over the crop application) using particular concentrate of herbicides caused damage to plantation indicated with symptom of leaves malformation (Sunindyo, 1998). Therefore, carefulness is required during application or spraying of herbicide by avoiding direct spray to main plantation. 


\section{CONCLUSION AND SUGGESTION}

1. For the success of the establishment of forest plantation including the one of Shorea selanica $\mathrm{Bl}$, which is mainly developed for construction wood, the maintenance of plantation including from weed control is required.

2. Undergrowths as potential weeds found in a five year old S. selanica Bl plantation were C. odorata, M. micrantha, L. camara, I. cylindrica, M. malabathricum, and B. latifolia.

3. Glyphosate and 2,4D-Amin herbicide could be applied to $S$. selanica Bl plantation to avoid weed disturbance.

4. For maintenance of S.selanica Bl plantation, Glyphosate and 2,4 D-Amin with dosage of 6.0 liter/ha could be used to control weeds under $S$. selanica Bl plantation

5. There was no symptom of poison in S. selanica Bl plantation, after the application of Glyphosate and 2, 4 D-Amin herbicide at all dosages applied. However, spraying technique should be done carefully by avoiding direct spray to main plantation.

6. Weed control should be done after dry season or in the beginning of rainy season, to avoid forest fire due to the availability of fuel potency derived from weed biomass in the field.

\section{REFERENCES}

Commission of Pesticide. 1994. Standard Method of Pesticide Efficacy Experiment. Commission of Pesticide. Ministry of Agriculture. Jakarta.

Garrity, D. P, M. Sukardi, M. Van Noordwijk, G. Huijun, and N. M. Majid. 1997. The Imperata grassland of Tropical Asia: Area, distribution and typology. Agroforestry System 36: 3-29. Kluwer Academic Publishers, Netherlands.

Gogoi, A. K. 2001. Status of Mikania infestation in Northeastern India : Management options and future research thrust. In: K. V. Sankaran, S. T. Murphy and H. C. Evans. (Eds.), Alien Weeds in Moist Tropical Zones : Banes and benefits. Proceedings of the Workshop held at Kerala Forest Research Institute. India.

Moraleedharan, P. K and V. Anitha, 2001. The economic impact of Mikania micrantha on the agroforestry production system in the Western Ghats of Kerala. In Sankaran, K.V, S.T. Murphy and Evans. H. C (Eds.). Alien Weeds in Moist Tropical Zones : Banes and Benefits. Proceedings of the Workshop held at Kerala Forest Research Institute. India.

Nazif, M. 1992. Efficacy trial of some herbicides to control weeds under mahogany plantation. Forest Research Bulletin No. 547. Bogor (In Indonesian).

Odum, E. P. 1971. Fundamental of Ecology. Third Edition. W.B. Sounders and Co. Philadelphia London Toronto. 
Schmidt, F. H. and J. H. A. Ferguson. 1951. Rainfall types based on wet and dry period ratios for Indonesia and Western New Guinea. Verh. No. 42. Directorate of Meteorology and Geophysic. Jakarta.

Singh, S. P. 2001. Biological control of invasive species in India. In: K.V. Sankaran, S.T. Murphy and Evans. H.C (Eds.). Alien Weeds in Moist Tropical Zones : Banes and benefits. Proceedings of the Workshop held at Kerala Forest Research Institute. India.

Soil Research Institute (LPT). 1966. Soil Map of West Java. Lembaga Penelitian Tanah. Bogor.

Steel, R. G. D and J. H. Torrie. 1981. Principles and Procedures of Statistics. Mc-Graw Hill International Book Company. Auckland-Tokyo.

Sunindyo. 1998. Starane $200 \mathrm{EC}$ as an alternative to control broadleaf weeds in Acacia mangium forest plantation area. In: F. G. Suratmo, S. Hadi, E. A. Husaeni, O. Rachmatsjah, Kaso, S. T. Nuhamara, N. F. Haneda (Eds). The issue and strategy of pest management in forest plantation area. Proceeding of the Workshop held at Bandungan, Central Java. Faculty of Forestry, Bogor Agricultural University and Ministry of Forestry. (In Indonesian)

Sushilkumar. 2001. Management of Lantana in India: Trend, prospect and need of integrated approach. In: Sankaran, K. V., S. T. Murphy and Evans. H. C (Eds.). Alien Weeds in Moist Tropical Zones: Banes and Benefits. Proceedings of the workshop held at Kerala Forest Research Institute. India.

Whitmore, T. C, I. G. M. Tantra, and U. Sutisna (Eds.). 1989. Tree Flora of Indonesia, Checklist for Maluku. Forestry Research and Development Agency. Bogor.

Wibowo, A. 2006. Imperata Grassland in Indonesia: Its susceptibility to fire and its control efforts. Info Hutan. Volume III No. 2. Pusat Litbang Hutan dan Konservasi Alam. Bogor. (In Indonesian). 
Appendix 1. Analysis of variance of weed biomass one month after Glyphosate and 2,4 D-Amin herbicide application under S. selanica plantation in Carita, Banten

\begin{tabular}{|c|c|c|c|c|c|c|}
\hline \multirow{2}{*}{$\begin{array}{c}\text { Source Of } \\
\text { Variation }\end{array}$} & \multirow{2}{*}{ Df } & \multirow{2}{*}{ SS } & \multirow{2}{*}{ MS } & \multirow{2}{*}{ F calc. } & \multicolumn{2}{|c|}{ F tab } \\
\hline & & & & & 0.5 & 0.1 \\
\hline Block & 3 & 0.146 & 0.049 & 0.484 & 3.07 & 4.87 \\
\hline treatment & 7 & 402.209 & 57.433 & 569.140 & 2.49 & 3.65 \\
\hline Error & 21 & 2.119 & 0.101 & & & \\
\hline Total & 31 & 404.474 & 13.042 & & & \\
\hline
\end{tabular}

$\mathrm{W}=\mathrm{Q}(\mathrm{p}, \mathrm{n}) \mathrm{Sx}$

$S_{x}^{-}=\sqrt{\frac{0.101}{3}}=0.18$

$\mathrm{W}(\mathrm{HSD}) 0.05>4.77 \times 0.18=0.86$ $0.01>5.48 \times 0.18=1.05$

Appendix 2. Analysis of variance of weed biomass two months after Glyphosate and 2,4 D-Amin herbicide application under S. selanica plantation in Carita, Banten

\begin{tabular}{lcccccc}
\hline \multirow{2}{*}{$\begin{array}{l}\text { Source Of } \\
\text { Variation }\end{array}$} & Df & SS & MS & F calc. & \multicolumn{2}{c}{ F tab } \\
\hline Block & 3 & 0100 & 0.533 & $\mathbf{0 . 1}$ \\
treatment & 7 & 706.576 & 100.939 & 1204.552 & 2.49 & 3.65 \\
Error & 21 & 1.760 & 0.084 & & & \\
Total & 31 & 708.436 & 22.853 & & & \\
\hline
\end{tabular}

$\mathrm{W}=\mathrm{Q}(\mathrm{p}, \mathrm{n}) \mathrm{Sx}$

$S_{x}^{-}=\sqrt{\frac{0.084}{3}}=0.17$

W $($ HSD $) \quad 0.05>4.77 \times 0.17=0.81$

$0.01>5.48 \times 0.17=0.99$ 
Appendix 3. Analysis of variance of weed biomass three months after Glyphosate and 2,4 D-Amin herbicide application under $S$. selanica plantation in Carita, Banten

\begin{tabular}{lrrrrrr}
\hline $\begin{array}{l}\text { Source Of } \\
\text { Variation }\end{array}$ & Df & SS & MS & F calc. & \multicolumn{2}{c}{ F tab } \\
\hline Block & 3 & 0.443 & 0.148 & 0.477 & 3.07 & $\mathbf{0 . 1}$ \\
treatment & 7 & 1053.451 & 150.493 & 485.479 & 2.49 & 3.65 \\
Error & 21 & 6.510 & 0.310 & & & \\
Total & 31 & 1060.404 & 34.207 & & & \\
\hline
\end{tabular}

$\mathrm{W}=\mathrm{Q}(\mathrm{p}, \mathrm{n}) \mathrm{Sx}$

$\mathrm{Sx}^{-}=\sqrt{\frac{0.310}{3}}=0.32$

W (HSD) $0.05>4.77 \times 0.32=1.53$

$0.01>5.48 \times 0.32=1.87$ 